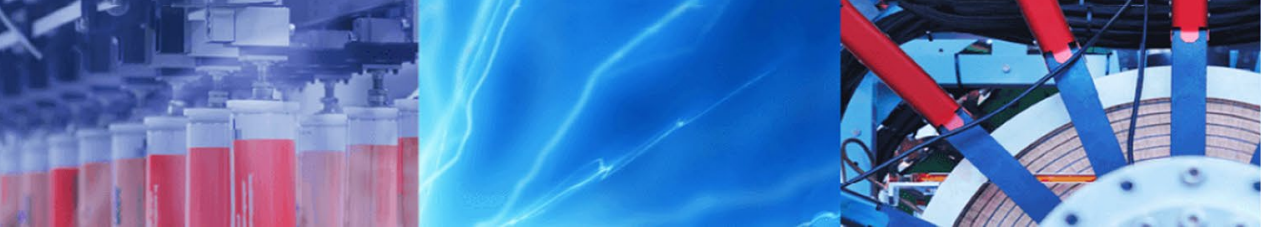

Research Article

\title{
Geochemical approach for heavy metals in suburban agricultural soils of Sialkot, Pakistan
}

\author{
Waqar Azeem Jadoon ${ }^{1,2}$ [D $\cdot$ Riffat Naseem Malik $^{3}$
}

(c) Springer Nature Switzerland AG 2019

\begin{abstract}
This study was designed to investigate heavy metals concentrations in the suburban agricultural soils with particular emphasis upon their risk assessment. Therefore, a total of 36 collected soil samples were investigated for heavy metals analysis by atomic absorption spectrophotometer. The results showed that the mean concentrations were $126.8 \mathrm{mg} \mathrm{kg}^{-1}$, $83.1 \mathrm{mg} \mathrm{kg}^{-1}$ and $118.5 \mathrm{mg} \mathrm{kg}^{-1}$ for $\mathrm{Cr}, \mathrm{Ni}$, and $\mathrm{Pb}$, respectively, higher than the Canadian and European Union permissible limits of metals in agricultural soils; while the concentrations of $\mathrm{Co}, \mathrm{Cu}$ and $\mathrm{Zn}$ were $34.7 \mathrm{mg} \mathrm{kg}^{-1}, 21.36 \mathrm{mg} \mathrm{kg}^{-1}$ and $92 \mathrm{mg} \mathrm{kg}^{-1}$, respectively, within permissible limits, and were higher than guideline values at some sites. However, enrichment factors showed a substantial anthropogenic input of the studied metals. A significant to very high enrichment was recorded for $\mathrm{Pb}$. Moreover, the geo-accumulation index revealed that these soils were moderately polluted with $\mathrm{Pb}$. In general, pollution load index indicated moderate pollution of soils, which was mainly caused by $\mathrm{Pb}$. The correlation and principal component analyses revealed that traffic emissions, tanneries, municipal waste and automobiles repair workshops were the predominant sources of $\mathrm{Pb}, \mathrm{Cr}$, Ni and $\mathrm{Co}$; whereas $\mathrm{Cu}$ and $\mathrm{Zn}$ are of geogenic origin in agricultural soils of Sialkot.
\end{abstract}

Keywords Heavy metals · Enrichment · Pollution · Risk assessment · Multivariate statistics · Suburban agricultural soil

\section{Introduction}

Unplanned urban and industrial expansion is causing an accumulation of heavy metals in suburban agricultural soils, which is a serious and growing concern in recent decades in Pakistan [1-3]. Such upsurges of metal concentrations are mainly caused by anthropogenic activities such as traffic emissions, use of agrochemicals, industrial/ municipal wastes and atmospheric deposition [2, 4]. The soil contamination with heavy metals is of special concern due to metal's ability to damage the soil environment, which can compromise soil ecological functions. Moreover, the long-term input of heavy metals could result in decreased buffering capacity of soil, further aggravating the threats to the ecological environment [5]. These metals can also be detrimental for living organisms through bioaccumulation and inclusion in the food chain, and inevitably compromise human health via ingestion $[4,6]$. Long-term consumption of contaminated food (with elements viz., $\mathrm{Cr}, \mathrm{Cd}, \mathrm{Pb}$, and $\mathrm{Ni}$ ) obtained from crops, which are grown in heavy metal contaminated soil, can cause accumulation of these metals in the human liver and kidneys, which can lead to organ malfunction [6]. In Pakistan, the excessive release of toxic metals from various sources and the general lack of environmental management have led to large-scale pollution of soils $[2,7]$.

Electronic supplementary material The online version of this article (https://doi.org/10.1007/s42452-019-0167-3) contains supplementary material, which is available to authorized users.

Waqar Azeem Jadoon, waqar.jadoon@gmail.com; waqar.jadoon@me.com | Department of Environmental Sciences, Hazara University, Mansehra, KPK, Pakistan. ${ }^{2}$ Graduate School of Biosphere Science, Hiroshima University, 1-7-1 Kagamiyama, Higashi-Hiroshima 739-8521, Japan. ${ }^{3}$ Department of Environmental Sciences, Quaid-i-Azam University, Islamabad 45320, Pakistan.

SN Applied Sciences (2019) 1:161 | https://doi.org/10.1007/s42452-019-0167-3

Received: 30 October 2018 / Accepted: 4 January 2019 / Published online: 14 January 2019 
It is particularly significant to evaluate the potential ecological risk and predict the pollution trend of heavy metal in these soils in order to carrying out a targeted control or prevention measures. Soil quality monitoring employing different environmental quality indices for the assessment of metal contamination has been carried out globally [7-13]. For example, the enrichment factor (EF) and geo-accumulation index $\left(I_{\text {geo }}\right)$ are utilized to evaluate the degree of anthropogenic influence on soil contamination by heavy metals, and to differentiate the metals originating from human activities and those from natural sources [14]. These indexes of potential contamination are calculated by the normalization of one metal concentration in the topsoil respect to the concentration of a reference element (Iron was chosen as reference element in this study). Similarly, the pollution load index (PLI) was applied for detecting pollution which permits a comparison of pollution levels between sites and at different times $[4,15]$. The PLI was obtained as a concentration factor of each heavy metal with respect to the background value in the soil. In this study, the world average concentrations of the metals studied reported for shale were used as the background for those heavy metals. The PLI is able to give an estimate of the metal contamination status and the necessary action that should be taken. The potential ecological risk index (RI) evaluates the potential ecological risk of heavy metals. This method comprehensively considers the synergy, toxic level, concentration of the heavy metals and ecological sensitivity of heavy metals [15]. Though, such indices are a powerful tool for the development and evaluation of environmental information, which will aid decision makers and environmental managers. However, there have been limited studies on soil quality monitoring in suburban agricultural fields of Pakistan that are significant sources of food but are exposed to nearby urban and industrial pollution. Identifying the sources of these metals also plays a basic role in controlling further pollution of agricultural lands.

Sialkot is an important industrial area of Pakistan housing 3229 unplanned industrial units erected within the city and around agricultural lands [2]. Unfortunately, these industries lack adequate waste disposal techniques and discharge their metal-enriched effluents directly into dug wells and water channels [7]. Irrigation of agricultural land by these contaminated water channels is a common practice in Sialkot district [3]. These contaminated agricultural soils might be of great public health concern when used to grow crops. In many agricultural areas, the problem of metals pollution is increasing in the absence of any adequate preventative measures. Therefore, ecological indices can be very useful tools for monitoring pollution to provide information for mitigation of agricultural areas. The objectives of this study are: (1) to determine metals concentrations viz., $\mathrm{Co}, \mathrm{Cr}, \mathrm{Cu}, \mathrm{Ni}, \mathrm{Pb}$ and $\mathrm{Zn}$ in suburban agricultural soils, (2) to evaluate the potential ecological risk using enrichment factor, rate of accumulation, potential load index, and potential ecological risk index; and (3) identification of various contributing sources of toxic metals in these soils.

\section{Materials and methods}

\subsection{Study area and surface soil sampling}

Sialkot district is located between $32^{\circ} 24^{\prime}-32^{\circ} 37^{\prime} \mathrm{N}$ latitude and $73^{\circ} 59^{\prime}-75^{\circ} 02^{\prime} \mathrm{E}$ longitude at an elevation of 244 masl in northeastern Pakistan at the foothills of the Pir Punjal Range of Azad Kashmir (Fig. 1). Sialkot district covers an area of $3016 \mathrm{~km}^{2}$ and its soils are categorized into four groups following soil taxonomy [16], i.e., Haplustalf's (order; alfisols), Ustochrepts (order; inceptisol), Ustofluvents (order; entisols), and Natrustalfs (order; alfisols) [7]. Periodic alluvial deposition confers the fertile nature of soils that in turn serves the agricultural activities in the area [3]. Export quality rice, wheat, sugarcane and barley are important crops of Sialkot. Irrigating these crops with stream water containing sewage waste emanated from the city and industries is common practice. Sometimes, during storms, the overflow of local streams spreads their hazardous contaminants onto these agricultural lands [2]. A total of 36 composite (combining 3 subsamples; $1.5 \mathrm{~kg}$ ) surface soil samples (depth: 3-15 cm) were collected from suburban agricultural soils (Fig. 1). The sampling was conducted before the onset of monsoon rainfall to avoid leaching and washing of metals from surface soils. The collected samples were cleaned for any coarse foreign material, stored in labeled polyethylene bags and transferred to the laboratory.

\subsection{Sample preparation and analytical procedures}

Air-dried soil samples were ground and sieved with a $2 \mathrm{~mm}$ pore size mesh sieve. Soil $\mathrm{pH}$, electrical conductivity (EC), and total dissolved solids (TDS) were measured in a 1:9 soil/deionized water suspension using a portable combined meter (Milwaukee, model SM 802). The soil texture was determined by estimating the percent sand, silt and clay in a given sample based on textural triangle using hydrometer method [17]. Organic matter (OM) was determined using the Walkley-Black wet-digestion method [18]. The heavy metals in soil samples were extracted by acid digestion following USEPA method $3051 \mathrm{~A}$ [2]. Briefly, a $0.5 \mathrm{~g}$ soil sample was digested with a $15 \mathrm{~mL}$ mixture of $\mathrm{HNO}_{3}(69 \%$ purity), $\mathrm{HCl}$ (28\% purity) and $\mathrm{HClO}_{4}$ (65\% purity) $\left(10 \mathrm{~mL} \mathrm{HNO}_{3}+2 \mathrm{~mL}\right.$ 


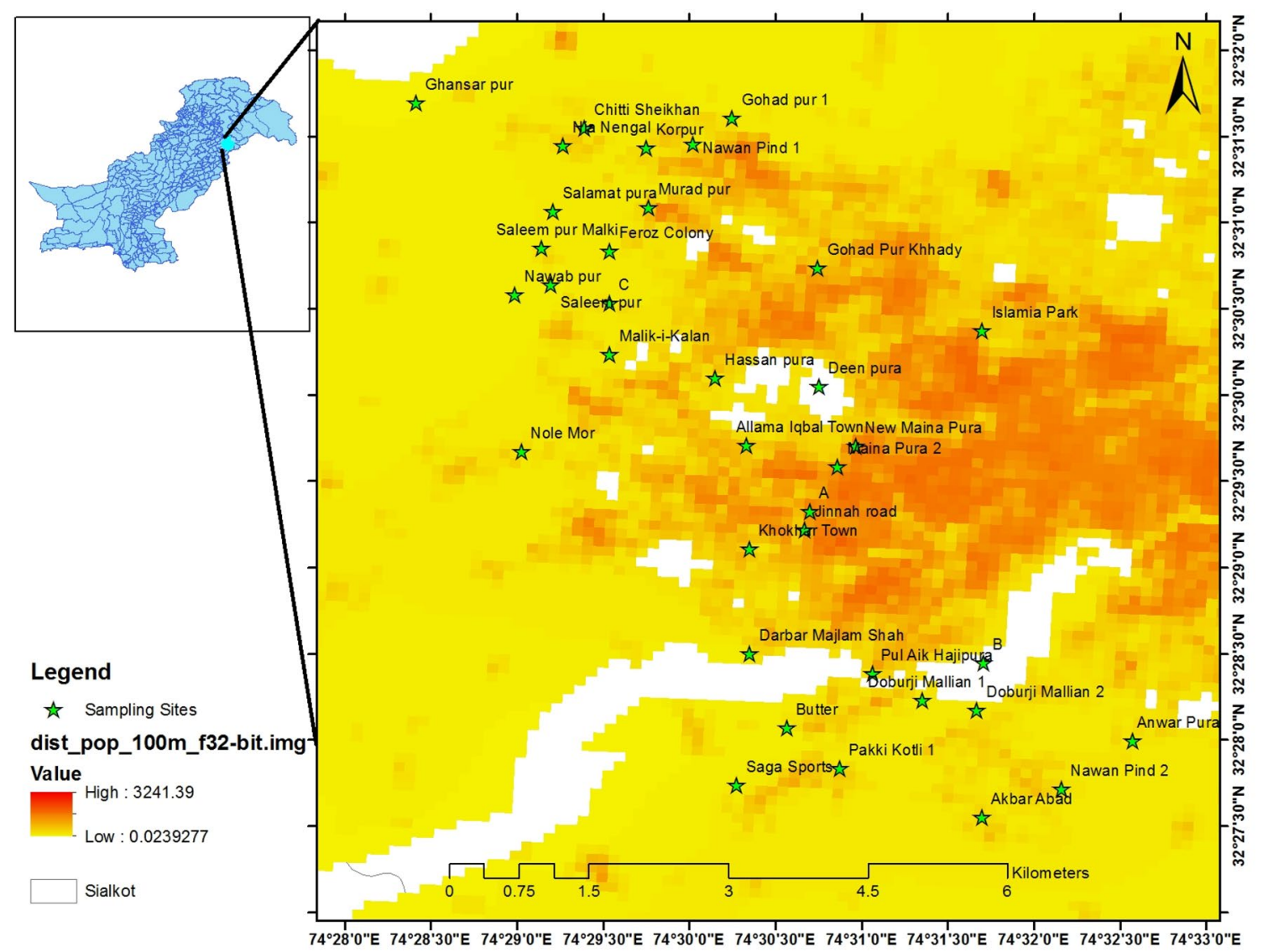

Fig. 1 Study area map showing the sampling sites (green stars) for suburban agricultural soils in Sialkot

$\left.\mathrm{HCl}+3 \mathrm{~mL} \mathrm{HClO}_{4}\right)$ in a microwave accelerated reaction system (MARS, CEM ${ }^{\circ}$ ) at $220^{\circ} \mathrm{C}$ for $30 \mathrm{~min}$. Thereafter, soil extracts were analyzed for total metal contents using fast sequential AAS (Varian FS-AA-240).

\subsection{Quality control/quality assurance}

Standard reference material (SRM) of the National Institute of Science and Technology (NIST, 2709 San Joaquin Soil) and an internal reference material were used for quality control and assurance. The chemicals, metal standards $\left(1000 \mathrm{mg} \mathrm{L}^{-1}\right)$ and other reagents of analytical grade were purchased from Sigma/Merck/Fluka. All glassware were washed with $10 \% \mathrm{HNO}_{3}$ and thereafter rinsed with deionized water. Each batch of analysis accompanied a reagent blank to check any cross contamination during extraction. All samples and blanks were extracted in triplicate to exclude procedural errors. The relative standard deviation (RSD), ranged from 5 to $10 \%$. Recovery rates of selected metals were within $90 \pm 10 \%$ and detection limits were $0.02-0.05 \mathrm{mg} \mathrm{kg}^{-1}$.

\subsection{Risk assessment and quantification of soil pollution}

\subsubsection{Enrichment factor (EF)}

The enrichment factor assessed the heavy metal pollution and their probable emission sources (anthropogenic and/or natural) using Eq. (1)

$\mathrm{EF}=\frac{\left(\frac{C_{\mathrm{i}}}{C_{\mathrm{M}}}\right)_{\text {sample }}}{\left(\frac{C_{\mathrm{i}}}{C_{\mathrm{M}}}\right)_{\text {background }}}$

where $\left(C_{\mathrm{i}} / C_{\mathrm{M}}\right)_{\text {sample }}$ and $\left(C_{\mathrm{i}} / C_{\mathrm{M}}\right)_{\text {background }}$ are the concentration ratios of target metal and reference metal (Iron) in the soil samples and in the background materials, respectively. 
Sutherland et al. [19] have developed five EF contamination levels (Table S1).

\subsubsection{Geo-accumulation index $\left(I_{\text {geo }}\right)$}

The $I_{\text {geo }}$ quantified the degree of heavy metal pollution in soil samples as:

$I_{\text {geo }}=\log _{2}\left(\frac{C_{n}}{1.5 B_{n}}\right)$

where $C_{n}$ is concentration of target metal in a given soil sample, $B_{n}$ is the geochemical background concentration of target metal in shale [20] and factor 1.5 was used to account the possible variations in the background values. Förstner et al. [21] listed seven $I_{\text {geo }}$ classes (Table S1).

\subsubsection{Pollution load index (PLI)}

The PLI is a multi-metal approach for an overall assessment of soil heavy metals contamination along with proper consideration to relative metal toxicity. The PLI is calculated through the following formula [22]:

$\mathrm{PLI}=\sqrt[n]{\mathrm{CF}_{1} \times \mathrm{CF}_{2} \times \mathrm{CF}_{3} \times \cdots \cdots \cdots \times \mathrm{CF}_{n}}$

where $\mathrm{CF}$ is the contamination factor and $n$ is the number of elements.

\subsubsection{Potential ecological risk index (RI)}

To quantify potential hazard from soil heavy metal contamination, the potential ecological risk index (RI) was used. The RI shows the sensitivity of the study area to soil metals contamination and presents potential ecological risks. The RI evaluates the metals contaminations and response of the environment as given in Eq. (4b).

$E_{\mathrm{r}}^{i}=\left(T_{i} \times f_{i}\right) ; \quad f_{i}=\left(\frac{C_{i}}{B_{i}}\right)$

(4a)
$\mathrm{RI}=\sum E_{r}^{i}$

where $f_{i}$ is metals contamination; $C_{i}$ is measured metal content in the soil sample; $B_{i}$ is background values of metals in uncontaminated soil; $E_{r}^{i}$ is potential ecological risk factor of individual metals; $T_{i}$ is toxic response factor suggested by Hakanson [23]; RI is potential ecological risk index of multiple metals. The risk factor for a single metal and risk index for multiple metals was taken from Hakanson [23] to assess soil metal pollution (Table S2).

\subsection{Statistical analyses}

Descriptive statistics, correlations, and PCA were determined using SPSS (version 20). PCA was applied to extract more significant variables and to eliminate the less significant variables [2, 24]. Varimax normalized rotation increased the variances of factor loadings across variables. Varimax factors with loading values of 1 or above were considered [25].

\section{Results and discussion}

\subsection{Physico-chemical parameters of agricultural soils}

The basic descriptive statistics for physico-chemical parameters in suburban agricultural soils are given in Table 1 (detailed information provided in Table S3). The soil types recorded in the study area were silt loam (39\%), loam $(36 \%)$, sandy loam $(11 \%)$ and sandy clay loam $(11 \%)$ (Fig. 2). These soils ranged narrowly in $\mathrm{pH}$ from 6.6 to 8.7, reflecting slightly saline soils. About $27.7 \%$ of soil samples had $\mathrm{pH}$ between 7 and $7.5,44.6 \%$ of samples had $\mathrm{pH}$ range
Table 1 Statistical summary of studied parameters in the suburban agricultural soils of Sialkot

\begin{tabular}{lrrrrrrr}
\hline Variables & \multicolumn{1}{c}{ Min } & \multicolumn{1}{c}{ Max } & \multicolumn{1}{c}{ Mean } & \multicolumn{1}{c}{ SD } & ASB $^{\mathrm{a}}$ & CCME $^{\mathrm{b}}$ & EU $^{\mathrm{c}}$ \\
\hline $\mathrm{pH}$ & 6.60 & 8.70 & 7.77 & 0.46 & - & - & - \\
$\mathrm{TDS}(\mathrm{ppm})$ & 40.00 & 280.00 & 123.61 & 52.05 & - & - & - \\
$\mathrm{OM}(\%)$ & 0.09 & 0.57 & 0.27 & 0.12 & - & - & - \\
$\mathrm{EC}(\mathrm{mS} / \mathrm{cm})$ & 0.07 & 0.41 & 0.18 & 0.07 & - & - & - \\
$\mathrm{Pb}\left(\mathrm{mg} \mathrm{kg}^{-1}\right)$ & 95.00 & 156.00 & 118.50 & 17.6 & 20 & 70 & 100 \\
$\mathrm{Cr}\left(\mathrm{mg} \mathrm{kg}^{-1}\right)$ & 81.80 & 457.20 & 126.77 & 71.82 & 90 & 64 & 100 \\
$\mathrm{Zn}\left(\mathrm{mg} \mathrm{kg}^{-1}\right)$ & 54.10 & 236.54 & 91.99 & 43.43 & 95 & 200 & 200 \\
$\mathrm{Ni}\left(\mathrm{mg} \mathrm{kg}^{-1}\right)$ & 62.60 & 110.60 & 83.14 & 10.53 & 68 & 50 & 70 \\
$\mathrm{Co}\left(\mathrm{mg} \mathrm{kg}^{-1}\right)$ & 23.60 & 46.00 & 34.70 & 6.69 & 19 & 40 & 50 \\
$\mathrm{Cu}\left(\mathrm{mg} \mathrm{kg}^{-1}\right)$ & 7.50 & 77.50 & 21.36 & 14.37 & 45 & 63 & 100 \\
\hline
\end{tabular}

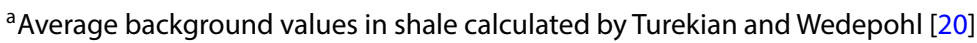

${ }^{b}$ Canadian soil quality guidelines for the Protection of Environmental and Human Health (CCME) [29]

'European Union soil quality guidelines [30] 


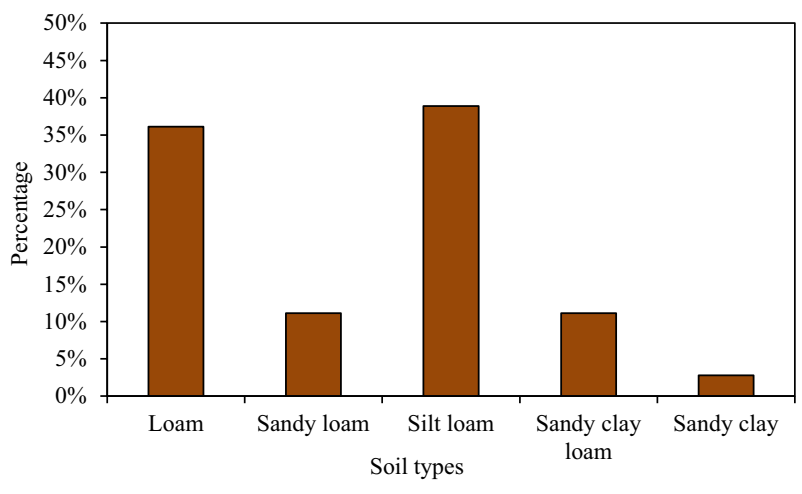

Fig. 2 Percentages of different soil types of the study area

of $7.6-8,25 \%$ had $\mathrm{pH}$ values above 8 and only $5.5 \%$ of soil samples were slightly acidic. The saline nature of the surface soil can be attributed to the presence of excessive calcium, magnesium and potassium salts $[2,26]$. Furthermore, sodium chloride might have increased soil salinity as it is used as animal hides preservative in tanneries and in later stages disposed to the water channels and soils [3]. OM, TDS, and EC concentrations were $0.09-0.57 \%$, 40-280 ppm and 0.07-0.41 $\mathrm{mS} \mathrm{cm}^{-1}$, respectively. Such low concentrations of $\mathrm{OM}$ may be the result of intensive agricultural practices and rapid mineralization in these soils under hot and humid conditions [2, 27]. TDS are comprised of inorganic salts and EC is the measure of these salts. The concentration of TDS in soil can be of natural (weathering of bedrocks) and anthropogenic (salts used hide preservatives in tanneries) origins [3]. However, TDS and EC values reported in this study were not harmful for agricultural soils and salinity sensitive crops. Soil physicochemical properties play an important role in metal accumulation and/or leaching in surface soils. For example, soil OM forms stable complexes with metals, which results in the accumulation of metals in given area $[13,28]$. The $\mathrm{pH}$ is another important variable in the retention of heavy metals in soil, which allows precipitation of metals at higher $\mathrm{pH}$ and their leaching at low $\mathrm{pH}$ [28].

\subsection{Heavy metal contents in suburban agricultural soils}

Descriptive statistics of trace elements such as minimum, maximum, mean and standard deviation in soils in Sialkot are summarized in Table 1. The elemental average concentrations $\left(\mathrm{mg} \mathrm{kg}^{-1}\right)$ in these soils decreased in the order of $\mathrm{Cr}>\mathrm{Pb}>\mathrm{Zn}>\mathrm{Ni}>\mathrm{Co}>\mathrm{Cu}$. The average concentrations of $\mathrm{Pb}, \mathrm{Cr}$, Ni and $\mathrm{Co}$ were 5.9, 1.4, 1.2 and 1.8 times as high as the background values in shale [20]. Moreover, the mean concentrations of $\mathrm{Pb}, \mathrm{Cr}$ and $\mathrm{Ni}$ were higher, whereas $\mathrm{Zn}, \mathrm{Co}$ and $\mathrm{Cu}$ were lower than their Canadian and European Union maximum permissible levels for agricultural soil quality (Table 1). Based on Canadian permissible levels for agricultural soils, $100 \%$ of the soil samples were moderately or heavily polluted by $\mathrm{Cr}, \mathrm{Ni}$ and $\mathrm{Pb}$. In relative terms, $\mathrm{Pb}$ was the leading contributor to heavy metal contamination followed by $\mathrm{Ni}$ and $\mathrm{Cr}$ in the study area. Presence of these metals in agricultural soils could be attributed to anthropogenic activities [2]. In this study, the agricultural soils close to the roads and urban areas showed higher concentration of $\mathrm{Pb}$ and $\mathrm{Ni}$ indicating their origin from traffic related activities. Micó et al. [31] suggested that atmospheric deposition of $\mathrm{Pb}$ could occur in soils near roads with considerable traffic, from solid particles and toxic fumes in the atmosphere. Similarly, Ali and Malik [10] also reported higher $\mathrm{Pb}$ and $\mathrm{Ni}$ contents along the roadside soils in Islamabad, indicating traffic input of these metals. Tanneries waste dumping and irrigation of crops with wastewater could cause various metals pollution of these soils $[2,3,7,32]$. However, in this study only $\mathrm{Cr}$ showed elevated concentration, suggesting its anthropogenic origin (tanneries waste). As the sampling was conducted before the monsoon season, the higher concentration of elements was due to prolonged drought conditions [13] and minimum leaching of these elements [2]. It can be concluded that anthropogenic activities may affect the input of $\mathrm{Cr}, \mathrm{Ni}, \mathrm{Pb}$ and $\mathrm{Co}$ in the study area and $\mathrm{Cu}$ and $\mathrm{Zn}$ may be of natural origin.

The mean values of metals were compared with the means of those reported elsewhere (Table 2). In this study, $\mathrm{Pb}, \mathrm{Cr}, \mathrm{Zn}$, and $\mathrm{Cu}$ concentrations were lower, while $\mathrm{Ni}$ and Co concentrations were similar to those obtained in earlier studies from Pakistan [10, 11,33]. Higher content of $\mathrm{Pb}, \mathrm{Zn}$, and $\mathrm{Cu}$ were reported from agricultural soils of Bangladesh and China in comparison with our study [5, 34]. Higher concentrations of metals in agricultural areas in Bangladesh and China compared with our study could be due to presence of coal mine and copper smelter around these agricultural fields. The $\mathrm{Pb}, \mathrm{Cr}, \mathrm{Zn}$ and Co concentrations found in this study were higher than those reported from agricultural soils in Greece, whereas $\mathrm{Ni}$ and $\mathrm{Cu}$ were lower than those reported from Greece [1]. Sharma et al. [35] reported lower concentrations of $\mathrm{Pb}, \mathrm{Cr}, \mathrm{Zn}$ and $\mathrm{Ni}$ from agricultural soils in Varanasi, India compared with current study. Moreover, levels of $\mathrm{Cr}, \mathrm{Cu}, \mathrm{Pb}$, and $\mathrm{Zn}$ were higher than those from Spain, Serbia and China $[28,31$, 36] (Table 2).

\subsection{Correlation analysis}

Organic matter (OM) showed a significantly positive correlation with $\mathrm{Zn}(0.472, p \leq 0.01)$ and $\mathrm{Cu}(0.392, p \leq 0.05)$ despite the fact that the OM content was low in the study area (Table 3). These results were consistent with those 
Table 2 Mean concentrations $\left(\mathrm{mg} \mathrm{kg}^{-1}\right)$ of metals in soils of the world in comparison with Sialkot, Pakistan

\begin{tabular}{llllllllll}
\hline Country & Soil type & $\begin{array}{l}\text { Number } \\
\text { of samples }\end{array}$ & $\mathrm{Pb}$ & $\mathrm{Cr}$ & $\mathrm{Zn}$ & $\mathrm{Ni}$ & $\mathrm{Co}$ & $\mathrm{Cu}$ & References \\
\hline Pakistan & Agricultural & 36 & 118.5 & 126.8 & 92 & 83.1 & 34.7 & 21.4 & Current study \\
Pakistan & Industrial & 25 & 152 & 301.6 & 359.4 & 58.8 & 32.5 & 144.8 & {$[11]$} \\
Pakistan & Agriculture & 10 & 217.5 & 475.5 & 907.9 & 78.1 & 0.6 & 229.8 & {$[33]$} \\
Pakistan & Urban & 834 & 209.2 & $\mathrm{NA}$ & 1658 & 90.8 & 16.3 & 17.4 & {$[10]$} \\
Greece & Agriculture & 132 & 19.5 & 83.1 & 74.9 & 146.8 & 21.99 & 74.7 & {$[1]$} \\
India & Agriculture & 173 & 17.8 & 94.2 & 74.7 & 14.5 & NA & 32 & {$[35]$} \\
China & Agriculture & 92 & 43.7 & 60.7 & 159 & 25.8 & NA & 105 & {$[5]$} \\
Bangladesh & Agriculture & 30 & 433 & $\mathrm{NA}$ & 296 & $\mathrm{NA}$ & $\mathrm{NA}$ & $\mathrm{NA}$ & {$[34]$} \\
Spain & Agriculture & 54 & 22.8 & 26.5 & 52.8 & 20.9 & $\mathrm{NA}$ & 22.5 & {$[31]$} \\
Serbia & Natural soil & 174 & 41.5 & 46.3 & 21.8 & 320 & NA & 8.6 & {$[36]$} \\
China & Paddy soil & 27 & 9.7 & 0.7 & 5.80 & NA & NA & 6 & {$[28]$} \\
\hline
\end{tabular}

NA not available

Table 3 The Pearson correlation coefficients among heavy metals and soil properties in suburban agricultural soils $(n=36)$

\begin{tabular}{|c|c|c|c|c|c|c|c|c|c|c|c|c|}
\hline & Sand & Silt & Clay & $\mathrm{pH}$ & EC & TDS & $\mathrm{OM}$ & $\mathrm{Pb}$ & $\mathrm{Cr}$ & $\mathrm{Zn}$ & $\mathrm{Ni}$ & Co \\
\hline Silt & $-0.862^{* *}$ & & & & & & & & & & & \\
\hline Clay & $0.454^{* *}$ & $-0.836^{* *}$ & & & & & & & & & & \\
\hline $\mathrm{pH}$ & 0.296 & -0.290 & 0.199 & & & & & & & & & \\
\hline $\mathrm{EC}$ & -0.197 & 0.144 & -0.044 & -0.279 & & & & & & & & \\
\hline TDS & -0.208 & 0.138 & -0.026 & -0.284 & $0.998^{* *}$ & & & & & & & \\
\hline $\mathrm{OM}$ & -0.128 & 0.011 & 0.064 & $-0.336^{*}$ & -0.150 & -0.145 & & & & & & \\
\hline $\mathrm{Pb}$ & -0.114 & -0.047 & 0.163 & -0.049 & -0.098 & -0.096 & 0.118 & & & & & \\
\hline $\mathrm{Cr}$ & -0.242 & 0.275 & -0.213 & -0.269 & 0.132 & 0.127 & 0.326 & -0.100 & & & & \\
\hline $\mathrm{Zn}$ & $-0.351^{*}$ & 0.288 & -0.143 & $-0.363^{*}$ & $0.349^{*}$ & $0.345^{*}$ & $0.472^{* *}$ & 0.213 & $0.526^{* *}$ & & & \\
\hline $\mathrm{Ni}$ & 0.067 & -0.249 & $0.350^{*}$ & -0.277 & 0.129 & 0.123 & 0.284 & $0.710^{* *}$ & 0.070 & $0.555^{* *}$ & & \\
\hline Co & 0.049 & -0.192 & 0.258 & -0.134 & -0.032 & -0.030 & 0.113 & $0.864^{* *}$ & -0.249 & 0.175 & $0.812^{* *}$ & \\
\hline $\mathrm{Cu}$ & -0.180 & 0.157 & -0.118 & $-0.335^{*}$ & $0.449^{* *}$ & $0.434^{* *}$ & $0.392^{*}$ & 0.123 & $0.466^{* *}$ & $0.854^{* *}$ & $0.493^{* *}$ & 0.087 \\
\hline
\end{tabular}

**Correlation is significant at the 0.01 level (2-tailed)

${ }^{*}$ Correlation is significant at the 0.05 level (2-tailed)

obtained by Dragović et al. [36] for natural surface soils of Zlatibor, Serbia. Cu was found preferably associated to soil $\mathrm{OM}$ and along with $\mathrm{Zn}$ also formed inner sphere complex with soil OM [36]. These relationships can be explained by the strong affinity of $\mathrm{Cu}$ and $\mathrm{Zn}$ to form complexes with $\mathrm{OM}$. It is well established that soil OM plays a fundamental role in reducing the mobility of metals in soil by forming stable complexes that might explain the correlation of $\mathrm{Cu}$ and $\mathrm{Zn}$ with OM $[13,28]$.

Similarly, $\mathrm{pH}$ also plays an important role in the retention of heavy metals in soil, such that at high $\mathrm{pH}$ metals tend to precipitate and lower $\mathrm{pH}$ promotes the dissolution of metals in water and making them more easily available [28]. However, significant negative correlations of $\mathrm{pH}$ were only observed with $\mathrm{Cu}$ and $\mathrm{Zn}$. The reason for the lack of significant correlation between $\mathrm{pH}$ and heavy metals might be attributed to a continuous input of metals, variations of pollution sources, soil type and fertilizer use within the sampling area [37]. Positive correlations of $\mathrm{Cu}$ and $\mathrm{Zn}$ were reported with EC and TDS, which could be due to their use in the tanneries during hide processing [3]. The significant correlation of $\mathrm{Cu}$ and $\mathrm{Zn}$ with many of the soil properties could be due to their high mobility, as, Antoniadis and Golia [27] also reported that even small changes in soil parameters can affect mobility of these metals. Soil particle size and proportion have significant impacts on metal accumulation [38]. However, in this study we could not find any correlation between soil particles and the heavy metals, which suggested that soil particles might have not played any significant role in heavy metals deposition.

Although a significant correlation is not always expected to be a common source, inter-element relationships could still provide interesting information on the 
sources and pathways of the metals [37]. High positive correlations were found among metals and they were categorized into two groups (Table 3). $\mathrm{Pb}, \mathrm{Ni}$ and Co showed very high positive correlation $(r 0.71-0.86, p \leq 0.01)$, grouped together indicating that these metals may have common emission sources. The second group comprised of $\mathrm{Cr}, \mathrm{Zn}$, and $\mathrm{Cu}$ with high positive correlation $(r 0.47-0.53, p \leq 0.01)$ may also share the same sources.

\subsection{Risk assessment using pollution indexes}

\subsubsection{Enrichment factor (EF)}

Enrichment factor (EF) provides interesting information about the geochemical trends and comparisons between areas to estimate the anthropogenic inputs of metals in soil [38]. With the help of EF, anthropogenic inputs of six metals' concentrations were calculated in the agricultural soils of Sialkot as shown in Table S5. This study illustrated that metals with average $\mathrm{EF}$ value $\mathrm{Pb}(15.33)>\mathrm{Co}$ (4.71) $>\mathrm{Cr}$ (3.69) $>\mathrm{Ni}(3.16)>\mathrm{Zn} \mathrm{(2.51)}>\mathrm{Cu}$ (1.24) were found in agricultural soils (Fig. 3). In this study, not even a single sampling site has extreme high enrichment of any metal as none of the metal has EF $>40$. Among studied metals $\mathrm{Pb}$ showed the highest $\mathrm{EF}$ value and ranged from 10.2 to 32.8 suggesting its significance regarding the very high enrichment in these soils. These agricultural soils were moderately to significantly enriched with $\mathrm{Cr}$ and $\mathrm{Co}$, and moderately enriched with $\mathrm{Ni}$ and $\mathrm{Zn}$.

The EF value fluctuates between 0.5 and 1.5 if the metal is of crustal origin or a result of natural weathering of rocks in a given area [4, 39]. However, in this investigation except $\mathrm{Cu}$ the ranges of EFs for metals exceeded the limit of 1.5 suggesting that significant proportions of these elements were of anthropogenic origin $[4,39]$.
Thus, the presence of these metals in the study area may be influenced by human activities such as emissions from traffic, industry (especially tanneries), pesticide/ fertilizer application, and automobile repair workshops $[2,4,8]$. All of these activities have been observed to contribute toxic metals in Sialkot district $[2,3]$. The EF values of $\mathrm{Cu}$ for almost all samples and $\mathrm{Zn}$ for more than half of studied samples are hovering around 1.5 indicating their natural input.

\subsubsection{Geo-accumulation index $\left(I_{\text {geo }}\right)$}

Geo-accumulation index was used for the estimation of toxic metals accumulation and the comparison of these metals in pre-industrial soils with those of agricultural soils of Sialkot [40]. The detailed information of $I_{\text {geo }}$ for the metals at different sampling sites is provided in Table S5. The $I_{\text {geo }}$ is not readily comparable to the other indexes of metal enrichment due to the nature of the $I_{\text {geo }}$ calculation, which involves a log function, and a background multiplication of 1.5 [16]. This was the reason of clearly different results of $I_{\text {geo }}$ from EF of the studied metals in soils. These metals were classified into their respective groups based on $I_{\text {geo }}$ index computed for the agricultural soils of Sialkot (Fig. 4). Figure 4 illustrates that $\mathrm{Pb}$ have mean $I_{\text {geo }}>$ 1 , while all other metals have mean $I_{\text {geo }}<1$. The $I_{\text {geo }}$ values for $\mathrm{Pb}$ ranged from 1.66 to 2.38 with an average value of 1.97 and represented moderately polluted soils. However, detailed analysis showed that $53 \%$ sites were moderately polluted and $47 \%$ were moderately to strongly polluted with $\mathrm{Pb}$. Soils were unpolluted to moderately polluted with Co based on the geo-accumulation index. The geoaccumulation calculation elucidated that agricultural soils were unpolluted with $\mathrm{Cr}$, $\mathrm{Cu} \mathrm{Ni}$, and $\mathrm{Zn}$.
Fig. 3 Enrichment factor (EF) for heavy metals in the suburban agricultural soils, Sialkot and $E F$ value (1.5) for natural inputs (red dotted line)

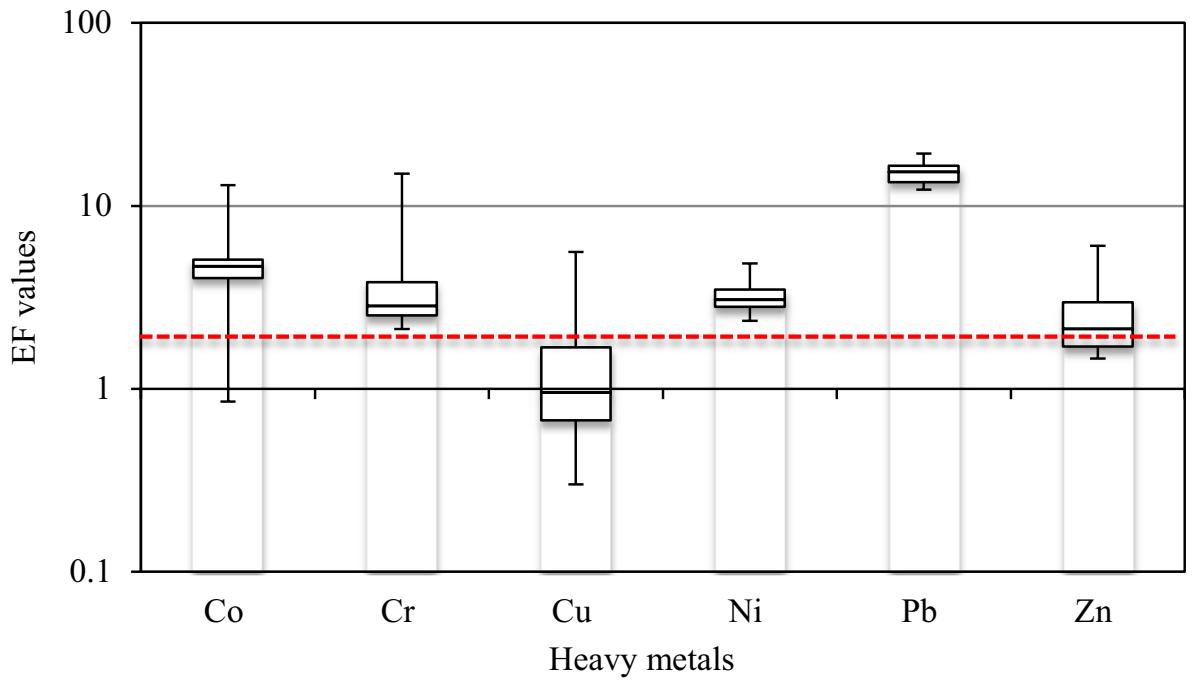

SN Applied Sciences A SPRINGER NATURE journa 


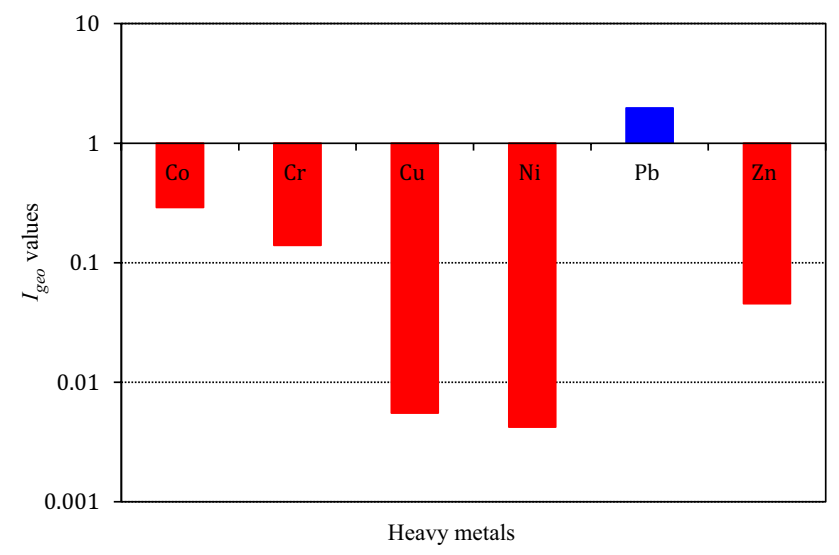

Fig. 4 Geo-accumulation index $\left(I_{\text {geo }}\right)$ for heavy metals in the suburban agricultural soils

\subsubsection{Pollution load index (PLI)}

The pollution load, as determined by the PLI, was variable over the investigated area. These PLI values showed the pollution load at each sampling site and are summarized in Table S5. The PLI values ranged from 0.92 to 2.33 with an average value of 1.38 (Table 4). The mean PLI was similar to the mean PLI reported for Korang river sediments from Pakistan [13] and in agricultural soils of Bangladesh [34]. Only two sites showed PLI values $>2$ and were assigned class $C_{2}$, which characterized these sites heavily polluted. The remaining 34 sites had PLI values $(0.92-1.89)<2$ (class $C_{1}$ ) and were considered moderately polluted. These PLI values revealed pollution in the study area is related to anthropogenic activities [13]. The highest PLI (2.33) was reported from a site near an industrial area and was also characterized by heavy traffic. Those sites with low PLI values were mostly situated in the outskirts of the city and comparatively far from roads and industrial units. The distribution of these PLI classes revealed that the agricultural soils in Sialkot are under the risk of metal pollution.

\subsubsection{Potential ecological risk index (RI)}

RI represents the sensitivity of the biological community to toxic substances and illustrates the potential ecological risk caused by the overall contamination of metals [12]. This study computed the risk factor $\left(E_{r}^{i}\right)$ for four toxic metals and RI was the sum of $E_{r}^{i}$ of these metals (Table 4). In this study $\mathrm{Pb}$ has the highest average $E_{\mathrm{r}}^{i}$ value (29.72). The $E_{r}^{i}$ values for $\mathrm{Cr}$, Zn and Cu were 2.82, 0.97 and 2.37, respectively. The $E_{r}^{i}$ values of all these metals were $<40$, which revealed low potential risk to soils by individual metals. The observed $E_{\mathrm{r}}^{i}$ for $\mathrm{Pb}, \mathrm{Cr}, \mathrm{Zn}$ and $\mathrm{Cu}$ were higher than those reported from a waste dumping site [9] and lower than those reported from an industrial area [11] in Pakistan. The potential ecological RI for the agricultural soils in the study area indicated low potential ecological risk. The total potential ecological risk was mainly caused by $\mathrm{Pb}$, which contributed $63-90 \%$ of the total risk. The mean $\mathrm{Rl}$ in this study was 12-18 folds lower than those reported from waste dumping and industrial sites from Pakistan (Table 4). This huge difference in RI values resulted from cadmium that has high toxic factors and cause the higher $\mathrm{RI}$ values [5]. Based on the estimates of the $E_{\mathrm{r}}^{i}$ and $\mathrm{Rl}$, it was concluded that the investigated soils had low metals contamination and the biological community of these soils are facing low potential ecological risk. Although there is low ecological risk, a more careful analysis is necessary for metals, especially with highly toxic factors (cadmium), when estimating their ecological risks in terms of the background values. Non-degradable metals may accumulate over a period of time and can pose a threat to humans on consumption of metals-enriched food. Therefore, it is recommended that care must be taken to not irrigate agricultural soils with wastewater and also control metals release in natural environments.

\subsection{Metals source identification using PCA}

The PCA was applied to find the possible emission sources of studied metals in the agricultural soils. Three principal components ( $\mathrm{PCs}$ ) with eigen values $>1$ explaining a total
Table 4 Potential ecological risk (Ei), risk index (RI) and pollution load index (PLI) of metals in suburban agricultural soils of Sialkot and comparison with other studies

\begin{tabular}{llllllll}
\hline Statistics & $\mathrm{Pb}$ & $\mathrm{Cr}$ & $\mathrm{Zn}$ & $\mathrm{Cu}$ & $\mathrm{RI}$ & $\mathrm{PLI}$ & References \\
\hline Min & 23.8 & 1.8 & 0.6 & 0.8 & 27.55 & 0.92 & Present study \\
Max & 39.0 & 10.2 & 2.5 & 8.6 & 47.92 & 2.33 & \\
Mean & 29.72 & 2.82 & 0.97 & 2.37 & 35.78 & 1.38 & \\
Mean & 0.64 & 0.03 & 0.47 & 2.81 & 432.49 & 0.20 & {$[9]$} \\
Mean & 112.8 & 377 & 10.66 & 76.2 & 644.66 & 21.83 & {$[11]$} \\
Mean & $\mathrm{NA}$ & $\mathrm{NA}$ & $\mathrm{NA}$ & $\mathrm{NA}$ & $\mathrm{NA}$ & 2.05 & {$[13]$} \\
Mean & $\mathrm{NA}$ & $\mathrm{NA}$ & $\mathrm{NA}$ & $\mathrm{NA}$ & $\mathrm{NA}$ & 2.87 & {$[34]$} \\
\hline
\end{tabular}

NA not available 
of $87 \%$ variance in the data were extracted (Table 5). PC1 explaining $35 \%$ of the total variance was positively loaded on $\mathrm{Pb}, \mathrm{Ni}$ and $\mathrm{Co}$. These metals may share the same emission source in the study area and are considered as common pollutants of urban areas $[2,4,12]$. The concentrations of these metals were higher than their earth's crust values in soil, therefore it could be concluded that they were anthropogenic in origin. Comparatively higher concentrations of $\mathrm{Pb}, \mathrm{Co}$ and $\mathrm{Ni}$ in agricultural fields along roadsides, low-lying areas and in close vicinity of the city could be related with anthropogenic input of these metals. Similar results in association to our results were also observed in earlier studies $[2,10,12,41]$ depicting that $\mathrm{Pb}$ from automobiles and atmospheric deposition and $\mathrm{Ni}$ from automobile and $\mathrm{Ni}-\mathrm{Cd}$ battery repair workshops caused the upsurge of these metals in agricultural surface soils. $\mathrm{Pb}$ is a well-known traffic related pollutant and $\mathrm{Ni}$ could also be related with automobile use [41]. Automobile and nickel-cadmium battery repair shops are significant sources of Ni pollution in the natural environment [10]. Qadir et al. [3] reported high levels of Ni from the tanneries effluents, which suggested that tannery industries could be another potential source of $\mathrm{Ni}$.

PC2 with positive significant loading of $\mathrm{Cr}, \mathrm{Zn}, \mathrm{Cu}$, and OM explained $29.1 \%$ of total variance. All soil samples were enriched with $\mathrm{Cr}$ indicating its substantial anthropogenic input. The soil samples collected near the tanneries or from those agricultural fields irrigated with sewage water were highly enriched with $\mathrm{Cr}$. In Sialkot, tanneries and other industries dispose of waste water containing $\mathrm{Cr}$ openly into the water channels $[2,3,32]$. Higher content of $\mathrm{Zn}$ was observed in samples collected near tanneries, which may be related with tanneries. However, most of the

Table 5 Principal component loadings of studied parameters in suburban agricultural soils $(n=36)$

\begin{tabular}{llll}
\hline Variables & PC1 & PC2 & PC3 \\
\hline $\mathrm{Pb}$ & $\mathbf{0 . 9 2}$ & 0.04 & -0.10 \\
$\mathrm{Cr}$ & -0.25 & $\mathbf{0 . 7 2}$ & 0.016 \\
$\mathrm{Zn}$ & 0.22 & $\mathbf{0 . 8 4}$ & 0.26 \\
$\mathrm{Ni}$ & $\mathbf{0 . 8 2}$ & 0.40 & 0.09 \\
$\mathrm{Co}$ & $\mathbf{0 . 9 6}$ & 0.01 & -0.02 \\
$\mathrm{Cu}$ & 0.16 & $\mathbf{0 . 7 8}$ & 0.38 \\
$\mathrm{pH}$ & -0.07 & -0.52 & -0.22 \\
$\mathrm{TDS}$ & -0.02 & 0.14 & $\mathbf{0 . 9 7}$ \\
$\mathrm{OM}$ & 0.06 & $\mathbf{0 . 7 4}$ & -0.34 \\
EC & -0.02 & 0.15 & $\mathbf{0 . 9 7}$ \\
Eigen value & 3.1 & 2.6 & 2 \\
\% total variance & 35 & 29.1 & 22.9 \\
\% cumulative variance & 35 & 64.1 & 87 \\
\hline
\end{tabular}

Boldfaced values shows loadings higher than 0.7 samples have lower content of $\mathrm{Zn}$, depicting its natural origin in the study area. The concentration of Cu was quite low and did not vary greatly in the study area. This uniform distribution may be indicating that $\mathrm{Cu}$ is of geogenic origin. High loading of OM on PC2 also justified the input of industry and municipal related pollutants. Leather processing results in an addition of hairs, skin, epithelial cells and pieces of meat in streams that, on degradation, serve as $\mathrm{OM}$; and municipal and house waste is another source of OM. Hence, tanneries and municipal waste could be the possible sources of $\mathrm{Cr}$ and in some areas of $\mathrm{Zn}$. However, $\mathrm{Cu}$ and $\mathrm{Zn}$ are of geogenic origin as well, which shows that $\mathrm{PC2}$ is the mixture of anthropogenic and natural sources. PC3 explaining $22.9 \%$ variation in the data is positively loaded by TDS and EC, which means that the value of EC increases along with TDS concentration. As discussed earlier, natural weathering and anthropogenic activities are adding salts to the soil in the study area. The results of multivariate analysis are consistent with those obtained by correlation analysis of heavy metal contents and soil physico-chemical characteristics. The PCA showed the attribution of the metals in two factors: the first one contained metals interpreted as related to traffic, automobiles batteries and atmospheric deposition. The second factor discriminated the tanneries, sewage waste and natural origin metals.

\section{Conclusions}

This study highlighted the significance of the high concentrations of $\mathrm{Pb}, \mathrm{Cr}$ and $\mathrm{Ni}$ that exceeded the CCME and EU maximum permissible levels of metals for agricultural soils and are therefore potential threats for the environment. The enrichment of these metals resulted in moderate to high contamination of suburban agricultural surface soils. This study revealed that $\mathrm{Pb}$ contributed to high soil enrichment and caused significant to very high pollution of these soils. Pollution load index indicated moderate pollution of soils, which was mainly caused by $\mathrm{Pb}$. However, there was low potential ecological risk caused by studied metals. Anthropogenic sources were major contributors in polluting the agricultural soils with metals. The PCA results visualized that the $\mathrm{Pb}, \mathrm{Cr}, \mathrm{Ni}$ and $\mathrm{Co}$ in the study area have their origin mostly from traffic, tanneries and municipal waste. However, $\mathrm{Cu}$ and $\mathrm{Zn}$ are of geogenic origin. The results of this study emphasized the need to restrict growing consumable food items on such contaminated lands with associated toxic metals. It is necessary to immediately regulate or even stop industrial waste disposal into agricultural soils and water systems, and refrain from using wastewater for agricultural purposes. 
Acknowledgements Dr. Zafeer Saqib and Dr. Abdul Qadir are highly acknowledged for their invaluable assistance during sample collection. Authors extend their gratitude to Mr. Tanweer Shirwani for his assistance during metal analysis.

Author contributions Both authors contributed in designing, data analysis and writing this paper, and approved the manuscript for possible publication in SN Applied Sciences.

\section{Compliance with ethical standards}

Conflict of interest On behalf of both authors, the corresponding author declare that there is no conflict of interest.

Ethical standards This study is in full compliance with all applicable ethical standards.

Ethical approval Human and/or animals were not subjected to collect any kind of data by any other for the purpose of this research.

\section{References}

1. Kelepertzis E (2014) Accumulation of heavy metals in agricultural soils of Mediterranean: insights from Argolida basin, Peloponnese, Greece. Geoderma 221-222:82-90

2. Malik RN, Jadoon WA, Hussain SZ (2010) Metal contamination of surface soils of industrial city Sialkot, Pakistan: a multivariate and GIS approach. Environ Geochem Health 32:179-191

3. Qadir A, Malik RN, Husain SZ (2008) Spatio-temporal variations in water quality of Nullah Aik-tributary of the river Chenab, Pakistan. Environ Monit Assess 140:43-59

4. Jadoon WA, Khpalwak W, Chidya RCG, Abdel-Dayem SMMA, Takeda K, Makhdoom MA, Sakugawa H (2018) Evaluation of levels, sources and health hazards of road-dust associated toxic metals in Jalalabad and Kabul Cities, Afghanistan. Arch Environ Contam Toxicol 74:32-45

5. Du P, Xie Y, Wang S, Zaho H, Zhang Z, Wu B, Li F (2015) Potential sources of and ecological risks from heavy metals in agricultural soils, Daye City, China. Environ Sci Pollut Res 22:3498-3507

6. Yang QW, Xu Y, Liu SJ, He JF, Long FY (2011) Concentration and potential health risk of heavy metals in market vegetables in Chongqing, China. Ecotoxicol Environ Saf 74:1664-1669

7. Ali Z, Malik RN, Shinwari ZK, Qadir A (2015) Enrichment, risk assessment, and statistical apportionment of heavy metals in tannery-affected areas. Int J Environ Sci Technol 12:537-550

8. Abrahim GMS, Parker RJ (2008) Assessment of heavy metal enrichment factors and the degree of contamination in marine sediments from Tamaki Estuary, Auckland, New Zealand. Environ Monit Assess 136:227-238

9. Aiman U, Mahmood A, Waheed S, Malik RN (2016) Enrichment, geo-accumulation and risk surveillance of toxic metals for different environmental compartments from Mehmood Booti dumping site, Lahore city, Pakistan. Chemosphere 144:2229-2237

10. Ali SM, Malik RN (2011) Spatial distribution of metals in top soils of Islamabad City, Pakistan. Environ Monit Assess 172:1-16

11. Hussain R, Khattak SA, Shah MT, Ali L (2015) Multistatistical approaches for environmental geochemical assessment of pollutants in soils of Gadoon Amazai Industrial Estate, Pakistan. J Soils Sediments 15:1119-1129
12. Sun Y, Zhou Q, Xie X, Liu R (2010) Spatial, sources and risk assessment of heavy metal contamination of urban soils in typical regions of Shenyang, China. J Hazard Mater 174:455-462

13. Zahra A, Hashmi MZ, Malik RN, Ahmed Z (2014) Enrichment and geo-accumulation of heavy metals and risk assessment of sediments of the Kurang Nallah-feeding tributary of the Rawal Lake Reservoir, Pakistan. Sci Total Environ 470-471:925-933

14. Luo XS, Xue Y, Wang YL, Cang L, Xu B, Ding J (2015) Source identification and apportionment of heavy metals in urban soil profiles. Chemosphere 127:152-157

15. Jiang X, Lu WX, Zhao HQ, Yang QC, Yang ZP (2014) Potential ecological risk assessment and prediction of soil heavy-metal pollution around coal gangue dump. Nat Hazards Earth Syst Sci 14:1599-1610

16. USDA (1999) Soil taxonomy. A basic system of soil classification for making and interpreting soil surveys, handbook no. 436. Soil Survey Staff, Washington, DC

17. Bouyoucos GJ (1962) Hydrometer method improved for making particle size analysis of soils. Agron J 54:464-465

18. Nelson DW, Sommers LE (1996) Total carbon, organic carbon, and organic matter. In: Sparks DL, Page AL, Helmke PA, Loeppert $\mathrm{RH}$, Soltanpour PN, Tabatabai MA, Johnston CT, Sumner ME (eds) Methods of soil analysis: part 3-chemical methods. American Society of Agronomy, Madison, pp 961-1010

19. Sutherland RA (2000) Bed sediment-associated trace metals in an urban stream, Oahu, Hawaii. Environ Geol 39:611-627

20. Turekian KK, Wedepohl KH (1961) Distribution of the elements in some major units of the Earth's crust. Geol Soc Am Bull 72:175-192

21. Förstner U, Ahlf W, Calmano W (1993) Sediment quality objectives and criteria development in Germany. Water Sci Technol 28:307-316

22. Tomlinson DL, Wilson JG, Hariis CR, Jeffrey DW (1980) Problems in the assessment of heavy metal levels in estuaries and the formation of a pollution index. Helgol Mar Res 33:566-575

23. Hakanson $L$ (1980) An ecological risk index for aquatic pollution control. A sedimentological approach. Water Res 14:975-1001

24. Jadoon WA, Sakugawa H (2016) Concentrations of polycyclic aromatic hydrocarbons: their potential health risks and sources at three non-urban sites in Japan. J Environ Sci Health A Toxic Hazard Subst Environ Eng 51:884-899

25. Jadoon WA, Kondo H, Sakugawa H (2015) Distribution and sources of particulate polycyclic aromatic hydrocarbons (PAHs) in air of Kamihaya, central Japan. Geochem J 49:207-217

26. Agnieszka B, Tomasz C, Jerzy W (2014) Chemical properties and toxicity of soils contaminated by mining activity. Ecotoxicology 23:1234-1244

27. Antoniadis V, Golia EE (2015) Sorption of $\mathrm{Cu}$ and $\mathrm{Zn}$ in low organic matter-soils as influenced by soil properties and by the degree of soil weathering. Chemosphere 138:364-369

28. Zeng F, Ali S, Zhang H, Ouyang Y, Qiu B, Wu F, Zhang G (2011) The influence of $\mathrm{pH}$ and organic matter content in paddy soil on heavy metal availability and their uptake by rice plants. Environ Pollut 159:84-91

29. CCME (2007) Canadian soil quality guidelines for the protection of environmental and human health. http://ceqg-rcqe.ccme.ca/ en/index.html\#void. Accessed 26 Dec 2017

30. Gawlik BM, Bidoglio G (2006) Background values in European soils and sewage sludges. European Commission, Brussels. http://eusoils.jrc.ec.europa.eu/ESDB_Archive/eusoils_docs/ other/eur22265_3.pdf. Accessed 25 Dec 2017

31. Micó C, Recatalá L, Peris M, Sánchez J (2006) Assessing heavy metal sources in agricultural soils of an European Mediterranean area by multivariate analysis. Chemosphere 65:863-872 
32. Ali Z, Malik RN, Qadir A (2013) Heavy metals distribution and risk assessment in soils affected by tannery effluents. Chem Ecol 29:676-692

33. Ahmad K, Khan Zl, Ashfaq A, Ashraf M, Yasmin S (2014) Assessment of heavy metal and metalloid levels in spinach (Spinacia oleracea L.) grown in wastewater irrigated agricultural soil of Sargodha, Pakistan. Pak J Bot 46:1805-1810

34. Bhuiyan MAH, Parvez L, Islam MA, Dampare SB, Suzuki S (2010) Heavy metal pollution of coal mine-affected agricultural soils in the northern part of Bangladesh. J Hazard Mater 173:384-392

35. Sharma RK, Agrawal M, Marshall F (2007) Heavy metal contamination of soil and vegetables in suburban areas of Varanasi, India. Ecotoxicol Environ Saf 66:258-266

36. Dragović S, Mihailović N, Gajić B (2008) Heavy metals in soils: distribution, relationship with soil characteristics and radionuclides and multivariate assessment of contamination sources. Chemosphere 72:491-495

37. Ma L, Sun J, Yang Z, Wang L (2015) Heavy metal contamination of agricultural soils affected by mining activities around the
Ganxi River in Chenzhou, Southern China. Environ Monit Assess 187:731-739

38. Çevik F, Göksu MZL, Derici OB, Findik O (2009) An assessment of metal pollution in surface sediments of Seyhan dam by using enrichment factor, geoaccumulation index and statistical analyses. Environ Monit Assess 152:309-317

39. Zhang J, Liu CL (2002) Riverine composition and estuarine geochemistry of particulate metals in China-weathering features, anthropogenic impact and chemical fluxes. Estuar Coast Shelf Sci 54:1051-1070

40. Loska K, Wiechuła D, Barska B, Cebula E, Chojnecka A (2003) Assessment of arsenic enrichment of cultivated soils in Southern Poland. Pol J Environ Stud 12:187-192

41. Kadi MW (2009) "Soil pollution hazardous to environment": a case study on the chemical composition and correlation to automobile traffic of the roadside soil of Jeddah city, Saudi Arabia. J Hazard Mater 168:1280-1283 